\title{
Special Issue on Turkish Foreign Policy
}

5 Editors' introduction: Special Issue on Turkish Foreign Policy

Mustafa Aydın and Kemal Kirişci

\section{Articles}

7 Globalization, Modernity and Democracy: In Search of a Viable Domestic Polity for a Sustainable Turkish Foreign Policy

E. Fuat Keyman

29 The Transformation of Turkish Foreign Policy: The Rise of the Trading State

Kemal Kirişci

57 Public Choice and Foreign Affairs: Democracy and International Relations in Turkey

Ersin Kalaycıoğlu

83 Facing its Waterloo in Diplomacy: Turkey's Military in the Foreign Policymaking Process

Gencer Ozcan

103 Securing Turkey Through WesternOriented Foreign Policy

Pınar Bilgin

125 Reconstructing Turkish-American Relations: Divergences Versus

Convergences

Mustafa Aydın
147 The Role of Temporality and

Interaction in the Turkey-EU

Relationship

Atila Eralp

169 Worldviews and Turkish Foreign

Policy in the Middle East

Meliha Benli Altunışık

193 Turkey and Eurasia: Frontiers of a New Geographic Imagination

Bülent Aras and Hakan Fidan

\section{Commentary}

217 Multiplying Vectors: A Framework

for Maximizing Turkey's Freedom in

Formulating and Implementing Foreign

Policy

ilter Turan

225 Turkish Foreign Policy: Limits of Engagement

Ahmet O. Evin

\section{Book Reviews}

233 Constantine Arvanitopoulos, ed.

Turkey's Accession to the European

Union: An Unusual Candidacy. Berlin:

Springer, 2009.

Aslı Toksabay Esen

236 Joseph S. Joseph, ed. Turkey and

the European Union: Internal Dynamics and External Challenges. Houndmills:

Palgrave Macmillan, 2006.

Sinem Akgül Açıkmeşe

ISSN 1305-3299 